\title{
ПРАВОВІ ТА ЕТИЧНІ ЗАСАДИ ГРОМАДСЬКОГО ЗДОРОВ'Я
}

\author{
${ }^{1}$ Одеський національний медичний університет, м. Одеса, Україна \\ ${ }^{2}$ ВДНзУ «Українська медична стоматологічна академія», м. Полтава, Україна
}

\begin{abstract}
Мета: проаналізувати правові та етичні засади громадського здоров'я.
Матеріали і методи. Методи дослідження обрані з урахуванням поставленої мети дослідження. Для встановлення об'єктивності та обґрунтованості наукових положень, висновків, під час проведеного дослідження застосовували комплекс загальнонаукових та спеціальних наукових методів, зокрема таких, як: формально-юридичний метод використовували для проведення аналізу правових та етичних засад громадського здоров'я; за допомогою порівняльно-правового методу з'ясовано підходи національного законодавства та міжнародних стандартів до етичного компонента громадського здоров'я, зокрема етична складова у правовому регулюванні діяльності лікарів, фрармацевтичних фрахівців, захисті пацієнтів, проведенні медичних досліджень та клінічних випробувань; метод прогнозування і моделювання використовували для розроблення практичних рекомендацій щодо значення аналізу правових та етичних засад громадського здоров'я у процесі ресормування системи охорони здоров'я України та імплементації Угоди про асоціацію між Україною та Європейським Союзом; метод системного аналізу дозволив дослідити правові та етичні засади громадського здоров'я як компонент системи охорони здоров'я України; історикоправовий метод дозволив виявити особливості еволюції правових та етичних засад громадського здоров'я.

Результати. Ефективність правового регулювання громадського здоров'я безпосередньо залежить від відповідності даних норм права засадам моралі та етики. Правовим та етичним зобов'язанням лікаря є абсолютна повага до життя людини, зберігання і відновлення фрізичного і психічного здоров'я людей. Етичні та правові норми у сорері громадського здоров'я відображені і в рекомендаційних документах, присвячених захисту прав пацієнтів.

Висновки. Положення національного законодавства та міжнародних стандартів у сорері громадського здоров'я поєднують правові та етичні засади при регулюванні діяльності лікарів, фрармацевтичних фахівців, захисті пацієнтів, проведенні медичних досліджень та клінічних випробувань. Ефективність та найвищий рівень необхідного забезпечення громадського здоров'я нерозривно пов'язані у реформуванні системи охорони здоров'я України відповідно до міжнародних стандартів, які поєднують етичну складову.
\end{abstract}

КЛЮчОВІ СЛОВА: громадське здоров'я; охорона здоров'я; права пацієнтів; медичне право.

Сорера охорони здоров'я є однією з найважливіших для життєдіяльності людини та суспільства в цілому. На державу покладено обов'язок створити належні умови для забезпечення необхідного рівня охорони здоров'я, які будуть спрямовані на реалізацію громадського (колективного) здоров'я, що включає і питання епідеміологічної безпеки, вакцинації/імунізації. Окрім правового забезпечення громадського (колективного) здоров'я важливою $є$ реалізація етичних засад. Етичний компонент громадського (колективного) здоров'я $€$ його соціальним фундаментом i набуває особливого значення за умов глобалізації. Саме сучасні виклики для сорери охорони здоров'я, які пов'язані з тенденціями міжнародних відносин, вимагають від держав прийняття правових заходів, що ґрунтуються на етичних засадах. До таких викликів варто віднести питання епідеміологічної безпеки, які можуть бути пов'язані у тому числі і з біотероризмом, боротьбу з неінфекційними захворюваннями, наприклад тютюнова епідемія, зростання онкологічних захворювань, а

(с О. О. Терзі, Н. О. Ляхова, Т. В. Плужнікова, 2019 також негативний вплив зміни клімату на охорону здоров'я.

Мета роботи: проаналізувати правові та етичні засади громадського здоров'я.

Матеріали і методи. Методи дослідження обрані з урахуванням поставленої мети дослідження. Для встановлення об'єктивності та обґрунтованості наукових положень, висновків, під час проведеного дослідження застосовували комплекс загальнонаукових та спеціальних наукових методів, зокрема таких, як: фрормально-юридичний метод використовували для проведення аналізу правових та етичних засад громадського здоров'я; за допомогою порівняльно-правового методу з'ясовано підходи національного законодавства та міжнародних стандартів до етичного компонента громадського здоров'я, зокрема етична складова у правовому регулюванні діяльності лікарів, фрармацевтичних фрахівців, захисті пацієнтів, проведенні медичних досліджень та клінічних випробувань; метод прогнозування і моделювання використовували для розроблення практичних рекомендацій щодо значення 
аналізу правових та етичних засад громадського здоров'я у процесі рефрормування системи охорони здоров'я України та імплементації Угоди про асоціацію між Україною та Європейським Союзом; метод системного аналізу дозволив дослідити правові та етичні засади громадського здоров'я як компонент системи охорони здоров'я України; історико-правовий метод дозволив виявити особливості еволюції правових та етичних засад громадського здоров'я. Використано також науково-евристичний потенціал таких фрілософських методів дослідження, як аналіз, синтез, дедукція, індукція, абстрагування тощо.

Результати дослідження та їх обговорення. Аналізуючи правові та етичні засади громадського здоров'я Т. А. Занфірова та Я. Ф. Радиш констатують, що, по-перше, питання щодо співвідношення норм права та моралі в структурі соціального регулювання медичної діяльності, яке необхідно розглядати з чотирьох позицій: єдність, відмінності, взаємодія, протиріччя, а, подруге, обов'язково пам'ятати й про те, що впродовж всього розвитку медицини сформувалися наступні рівні соціального регулювання медичної діяльності - лікарська (медична) етика та медична деонтологія, біомедична етика (біоетика) i медичне право [6]. Таким чином, Т. А. Занфрірова та Я. Ф. Радиш демонструють багатокомпонентність сорери громадського здоров'я та взаємодоповненість правового та етичного, морального компонентів, а також вони виокремлюють як рівень соціального регулювання медичної діяльності медичну деонтологію. Існує багато дефініцій медичної деонтології, але комплексною, яка поєднує правову і етичну складову, є наступна: медична деонтологія - це вчення про належний спосіб спілкування, поведінки; комплекс етичних правил, норм і принципів, якими керується лікар; морально-етичний компонент діяльності лікаря; сукупність відповідних професійних, моральноетичних і правових принципів і правил, складових поняття лікарського обов'язку [10].

Як вказує О. А. Гриценко, що за умов проведення реформи медичної сорери, появи нових видів медичних явищ - трансплантації, сурогатного материнства, генетичних технологій, персоніфікованої медицини, кріокремації, екологічної реабілітації, медичного туризму, клонування тощо, значно зростає роль та значення правової науки, яка виокремлює проблематику охорони здоров'я в особливу галузь - медичне право [1]. Медичне право, в свою чергу, відображає і етичну складову, на якій ґрунтуються приписи права у сорері охорони здоров'я та медицини.

Ефективність правового регулювання громадського здоров'я безпосередньо залежить від відповідності даних норм права засадам моралі та етики. Саме у сорері громадського здоров'я правові норми повинні ґрунтуватися на засадах етики та моралі. Етична, моральна складова громадського здоров'я має довгу еволюцію. Становленню медичної етики сприяли видатні античні лікарі та фрілософи Індії, Месопотамії, Єгипту, Греції, Риму [4]. А. Д. Рамішвілі, В. І. Вітер та Н. І. Неволін вказують, що цілком природно, що етичні норми в медицині зазнавали змін, зумовлені розвитком як суспільних відносин, так і самої галузі, але при цьому їхня сутність, фрілантропічна спрямованість, гуманістична основа, протягом більш ніж двох минулих тисячоліть, практично не змінилися [8]. Сучасне ставлення до етики у сорері громадського здоров'я та медицини відображені в Женевській декларації 1948 р. і Міжнародному кодексі медичної етики 1949 р.

Однією 3 передумов ефрективного фрункціонування національної системи охорони здоров'я, як зазначають Г. В. Гусева та С. Г. Убогов, $€$ неухильне дотримання принципів професійної етики і деонтології медичними та фармацевтичними працівниками [2]. Г. В. Гусева та С. Г. Убогов вказують, що дана вимога закріплена в пункті «г» статті 78 Закону України «Основи законодавства України про охорону здоров'я», що зумовлено визначеністю охорони здоров'я як пріоритетного напряму державної політики та фрактора національної безпеки країни [2].

Основою етичної засади громадського здоров'я $€$ усвідомлення, що життя та здоров'я людини це головні, фундаментальні цінності, як це закріплено в Етичному кодексі лікаря України. Етичний кодекс лікаря України покладає обов'язок на лікаря пам'ятати, що головний суддя на його професійному шляху є совість. Варто зазначити, що лікар виконує свої обов'язки з повагою до життя, гідності та особистості кожного пацієнта на основі морально-етичних принципів суспільства, які ґрунтуються на Клятві лікаря України та Етичному кодексі лікаря України. А правовий компонент громадського здоров'я повинен забезпечити захист морально-етичних позицій і принципів лікарів, особистої гідності лікарів, створення належних умов для здійснення професійної лікарської діяльності. Етичні комісії та комітети при закладах охорони здоров'я і наукових установах; медичних та наукових фредераціях, асоціаціях, товариствах та інших громадських організаціях у галузі охорони здоров'я покликані здійснювати контроль та забезпечувати етичність діяльності медичних працівників. Етичні комісії та комітети наділені здатністю застосовувати санкції до порушників положень Етичного кодексу лікаря України.

У рекомендаційному акті, який є «компасом» у діяльності лікаря, Женевській декларації Всесвітньої медичної асоціації (Міжнародна клятва лікарів), яка була прийнята другою Генеральною асамблеєю Всесвітньої медичної асоціації у 
вересні 1948 р. (Женева, Швейцарія), доповнена двадцять другою Всесвітньою медичною асамблеєю у серпні 1968 р. (Сідней, Австралія), і тридцять п'ятою Всесвітньою медичною асамблеєю у жовтні 1983 р. (Венеція, Італія), вказано, що вступаючи в медичне співтовариство лікар добровільно вирішує присвятити своє життя служінню ідеалам гуманності. Також лікар бере зобов'язання у абсолютній повазі до людського життя з моменту її зачаття, і ніколи, навіть під загрозою, не використовуватиме своїх медичних знань на шкоду нормам гуманності.

У Міжнародному кодексі медичної етики, який був прийнятий третьою Генеральною асамблеєю Всесвітньої медичної асоціації у жовтні 1949 р. (Лондон, Велика Британія), доповнений двадцять другою Всесвітньою медичною асамблеєю у серпні 1968 р. (Сідней, Австралія) і тридцять п'ятою Всесвітньою медичною асамблеєю у жовтні 1983 р. (Венеція, Італія), зазначено, що лікар повинен ставити в основу своєї діяльності співчуття і повагу до людської гідності пацієнта.

Токійською декларацією, яка була прийнята двадцять дев'ятою Всесвітньою медичною асамблеєю у жовтні 1975 р. (Токіо, Японія), встановлено, що лікар зобов'язаний служити людству, зберігаючи і відновлюючи фрізичне і психічне здоров'я людей, полегшувати страждання пацієнтів, незалежно від їхніх особистих якостей і проявів та повинен виявляти абсолютну повагу до життя людини, починаючи 3 моменту її зачаття, і ніколи, навіть під загрозою, не може використовувати свої професійні знання всупереч законам гуманності.

Отже, правовим та етичним зобов'язанням лікаря $€$ абсолютна повага до життя людини, зберігання і відновлення фрізичного й психічного здоров'я людей.

Етичний компонент відображений і в Етичному кодексі фрармацевтичних працівників у декількох аспектах. По-перше, в Кодексі визначено, що етичні норми професійної поведінки та відповідальності мають стати взірцевим керівництвом для провізорів та фрармацевтів у їх взаємовідносинах із суспільством за умов фрормування ринкових відносин, коли зростає роль та вагомість фрармацевтичної профресії.

По-друге, Кодекс призначений для регулювання етичних взаємовідносин фрармацевтичних працівників, пов'язаних із професійною сорерою їх діяльності, у разі конфрліктних ситуацій шляхом залучення спеціальних уповноважених органів (комітетів із фрармацевтичної етики тощо).

По-третє, Кодекс містить вимоги щодо реклами, так, неетичною рекламу варто вважати, яка вводить в оману щодо рекламованого товару та містить некоректні порівняння $з$ товарами інших виробників і недотримання принципів законності, професіоналізму, об'єктивності, коректності реклами $є$ порушенням етичних норм просування (дистрибуції) лікарських засобів та медичної продукції тощо.

По-четверте, Кодекс містить етичні вимоги щодо професійних відносин між колегами, так, фармацевтичний працівник має бути носієм високих морально-етичних принципів своєї профресії, добродійним, чесним і справедливим, дотримуватися прийнятих у колективі морально-етичних традицій, надавати допомогу і передавати профресійний досвід молодим колегам, сприяти їх етичному вихованню.

По-п'яте, Кодекс зобов'язує фрармацевтичних працівників сприяти проведенню різного роду досліджень (медико-фрармацевтичних, організаційно-економічних, фрармако-економічних, маркетингових, соціологічних та інших), метою яких $€$ підвищення ефективності та доступності надання населенню фрармацевтичної допомоги та які узгоджені з відповідним етичним комітетом, а також має запобігати проведенню псевдонаукових досліджень, що не відповідають загальновизнаним гуманним принципам, морально-етичним нормам та етнокультурним і релігійним особливостям регіонів, де вони працюють.

По-шосте, етичні та правові засади поєднуються у Кодексі щодо клінічних випробувань нових лікарських засобів, розроблених на основі новітніх фармацевтичних технологій, які повинні проводитися згідно з етичними принципами Гельсінської декларації, правилами GCP та відповідними регуляторними вимогами [3].

Також необхідно розглянути правовий компонент Етичного кодексу фрармацевтичних працівників. Кодекс спрямований на захист гідності та права на охорону здоров'я людини і суспільства в цілому, а також визначає права та моральну відповідальність фрармацевтичних працівників. Кодекс ґрунтується на положеннях Конституції України, Цивільного кодексу України, законах України «Основи законодавства України про охорону здоров'я», «Про лікарські засоби», «Про захист прав споживачів», «Про рекламу» та інших нормативно-правових актах України. Відповідно до положень Кодексу взаємовідносини фрармацевтичного працівника і пацієнта ґрунтуються на повазі до гідності та честі, пріоритеті прав та інтересів пацієнта. У своїй діяльності фармацевтичний працівник повинен неухильно дотримуватися Конституції України, не зазіхати на права та свободи, честь і гідність інших людей.

Отже, Етичний кодекс фрармацевтичних працівників України є рекомендаційним актом, проте він демонструє поєднання етичних та правових приписів та ґрунтується на положеннях чинного 
законодавства України та міжнародних стандартів у сорері громадського здоров'я та фрармацевтики.

Етичні та правові норми у сфері громадського здоров'я відображені і в рекомендаційних документах, присвячених захисту прав пацієнтів. Лісабонська декларація про права пацієнта, яка була прийнята тридцять четвертою Всесвітньою медичною асамблеєю у вересні-жовтні 1981 р., регламентує, що будь-який пацієнт має право отримувати допомогу лікаря, який, на його думку, має право приймати професійні медичні та етичні рішення незалежно від стороннього впливу.

У Декларації про політику в галузі забезпечення прав пацієнта в Європі (Амстердамська декларація), яка була прийнята Всесвітньою організацією охорони здоров'я у 1994 р., гарантується, що кожна людина має право на фрізичну і духовну цілісність і на особисту безпеку та має право на охорону здоров'я, забезпечувану застосуванням адекватних лікувально-профрілактичних заходів, а також право для можливості максимального підвищення рівня власного здоров'я.

Етичний та правовий компонент у сорері громадського здоров'я розкривається через призму прав людини. Міжнародно-правовим стандартом, який поєднав права людини та етичність у сорері біомедицини, є Конвенція про захист прав і гідності людини щодо застосування біології та медицини: Конвенція про права людини та біомедицину (1997р.). Так, п. III статті 16 «Захист осіб, на яких проводяться наукові дослідження» Конвенції про права людини та біомедицину (1997р.) закріплює, що наукове дослідження на людині можна проводити тільки за умови, що проект дослідження затверджений компетентним органом після проведення незалежної експертизи його наукової цінності, включаючи оцінку важливості мети дослідження, та багатодисциплінарного розгляду його прийнятності з етичної точки зору. У статті 28 «Публічне обговорення» Конвенції про права людини та біомедицину (1997р.) встановлено, що сторони Конвенції слідкують за тим, щоб фрундаментальні питання, які постають у зв'язку із досягненнями у галузі біології та медицини, були предметом належного публічного обговорення з урахуванням, зокрема, відповідних медичних, соціальних, економічних, етичних і правових наслідків та щоб їхнє можливе застосування було предметом відповідних консультацій. Тобто стаття 28 Конвенції про права людини та біомедицину (1997 р.) встановлює нерозривність етичного та правового компонента у медичній та біологічній сорерах. Отже, при здійсненні будь-якої діяльності у сорері громадського здоров'я необхідно керуватися як правовими засадами, так і етичними у їх синтезі.
Поєднання етичних та правових засад при здійсненні медичних досліджень міститься у Гельсінській декларації Всесвітньої медичної асоціації «Етичні принципи медичних досліджень за участю людини в якості об'єкта дослідження», яка була прийнята у 1964 р. У Декларації 1964 р. закріплено обов'язок лікаря підтримувати та охороняти здоров'я пацієнтів, у тому числі й тих, котрі залучені до медичних досліджень, а знання та совість лікаря присвячені виконанню цього обов'язку. Також встановлено, що у медичних дослідженнях за участю людини як об'єкта дослідження благополуччя кожного об'єкта дослідження має бути пріоритетним серед інших інтересів. щодо медичних досліджень в Декларації 1964 р. прописано, що вони повинні відповідати етичним стандартам, які заохочують повагу до всіх людей та захист їхнього здоров'я і їхніх прав.

Необхідно зазначити, що правовий та етичний компонент у сорері громадського здоров'я містяться в главі 22 «Громадське здоров'я» Угоди про асоціацію між Україною та Європейським Союзом, у якій визначено основні його сорери, а саме: зміцнення системи охорони здоров'я України; запобігання і контроль над інфекційними хворобами (забезпечення імплементації Міжнародних медико-санітарних правил (2005)); у сорері і контроль за неінфекційними хворобами; якість та безпечність субстанцій людського походження; інформація та знання в галузі охорони здоров'я (ст. 427) [9]

Можливо навести приклад поєднання етичної та правової складової при проведенні клінічних випробувань лікарських засобів. Усі випробування лікарських засобів за участю людини повинні проводити відповідно до загальновизнаних етичних принципів, а саме: 1) принцип автономії (визнання спроможності людини робити свій вибір). Принцип автономії реалізується, зокрема, шляхом процедури добровільної інорормованної згоди, яка може бути відкликана в будь-який час і без будь-яких наслідків для людини; 2) принцип користі та непричинення шкоди (користь та непричинення шкоди - моральне зобов'язання забезпечувати максимум потенційної користі і мінімізації можливої шкоди); 3) принцип справедливості (справедливість - неупередженість і рівність). Справедливість має велике значення особливо для відбору учасників дослідження. Критерії відбору повинні бути пов'язані з метою дослідження, а не мати за основу лише, наприклад, легкість, з якою могла бути отримана інформована згода [5].

Основою базових принципів при проведенні клінічних випробувань лікарських засобів, які поєднують права людини та етичність, є необхідність поваги і захисту людської гідності та її 
життя і здоров'я, честі та гідності, недоторканості і безпеки, захисту прав і свобод відповіднодо принципу пріоритету людини. Відповідно до цього принципу інтереси і благополуччя людини, яка бере участь у дослідженні, завжди повинні переважати над інтересами науки і суспільства. Важливу роль у забезпеченні принципу пріоритету людини відіграють комісії з питань етики. Комісії 3 питань етики відповідають за забезпечення прав, безпеки, благополуччя досліджуваних та за надання суспільству відповідних гарантій, а незалежна оцінка наукової користі проекту (протоколу КВ) дослідження і його експертиза з точки зору етичної прийнятності гарантує дотримання етичних та морально-правових принципів проведення біомедичних досліджень [5].

У Керівництві 1 «Наукове та соціальне значення і дотримання прав» Ради міжнародних організацій медичних наук та Всесвітньої організації охорони здоров'я вказано, що етичним обґрунтуванням для проведення досліджень за участю людини, що стосується питань здоров'я, $€$ його наукове і соціальне значення в перспективі формування знань і засобів, необхідних для захисту і зміцнення здоров'я людей. Таким чином, для того, щоб бути етично прийнятними, дослідження, що стосується питань здоров'я за участю людини, в тому числі дослідження із використанням зразків тканин людини або даних про людину, повинні мати соціальне значення [7]. Етичний та правовий компонент відображений у тому, що, крім етичної прийнятності, всі дослідження за участю людини повинні демонструвати повагу і турботу про права і благополуччя окремих учасників і спільнот, в яких проводиться дослідження. Економічне питання розкрито у Керівництві 2 «Дослідження, що проводяться в умовах 3 низьким рівнем забезпеченості ресурсами» Ради міжнародних організацій медичних наук та Всесвітньої організації охорони здоров'я, де вказано, що етичні стандарти, що застосовують для досліджень у сорері медицини не залежать від рівня забезпеченості ресурсами. Отже, етичність не може бути обмежена через недостатність ресурсів. Етична складова будь-якого дослідження у сорері медицини $є$ імперативною.

\section{Висновки}

Положення національного законодавства та міжнародних стандартів у сорері громадського здоров'я поєднують правові та етичні засади при регулюванні діяльності лікарів, фрармацевтичних фахівців, захисті пацієнтів, проведенні медичних досліджень та клінічних випробувань. Ефективність та найвищий рівень необхідного забезпечення громадського здоров'я нерозривно пов'язані у реформуванні системи охорони здоров'я України відповідно до міжнародних стандартів, які поєднують етичну складову. Рефрормування системи охорони здоров'я України повинно відбуватися у зв'язку з імплементацією Угоди про асоціацію між Україною та Європейським Союзом, а саме положень глави 22 «Громадське здоров'я» та інших рекомендаційних актів Всесвітньої організації охорони здоров'я та Всесвітньої медичної асоціації (міжнародна неурядова організація).

Перспективи подальших досліджень. Тематика правових та етичних засад громадського здоров'я актуальна та $€$ необхідними подальші дослідження у світлі реформування системи охорони здоров'я України.

\section{Список літератури}

1. Гриценко О. А. Здоров'я людини як об'єкт правового регулювання [Електронний ресурс] / О. А. Гриценко. - Режим доступу : http://hnpu.edu.ua/sites/default/files/files/Kaf_zdor_ta_korr_os/Zagalna_teorija_zdorovia_i_zdorviazberegennja. pdf.

2. Гусева Г. В. Законодавчі аспекти забезпечення дотримання етичних норм у сфері охорони здоров'я / Г. В. Гусева, С. Г. Убогов // Інтегративна Антропологія. - 2016. - № 1 (27). - С. 17-21.

3. Етичний кодекс фрармацевтичних працівників України [Електронний ресурс]. - Режим доступу : http://nuph.edu.ua/ etichnijj-kodeks-farmacevtichnih-prac.

4. Загальні принципи організації діяльності комісій з питань етики при лікувально-профрілактичних закладах, в яких проводяться клінічні випробування лікарських засобів : посібник / Л. Ковтун, Л. Янкова, С. Распутняк та ін. К., 2017. -48 c.

5. Занфрірова Т. А. Етико-правові засади регулювання медичної діяльності в Україні (за матеріалами літературних джерел) [Електронний ресурс] / Т. А. Занфрірова, Я. Ф. Радиш. - Режим доступу : http://medicallaw.org.ua/uploads/ media/02_124_01.pdf.

6. Запорожан В. М. Біоетика та біобезпека : підручник / В. М. Запорожан, М. Л. Аряєв. - К. : Здоров'я, 2013. - 456 с. 7. Міжнародні етичні рекомендації щодо досліджень, пов'язаних із здоров'ям, за участю людей [Електронний peсурс]. - Режим доступу : http://www.dec.gov.ua/site/files/klinika/cioms.pdf.

8. Рамишвили А. Д. Современные проблемы этики и права в здравоохранении / А. Д. Рамишвили, В. И. Витер, Н. И. Неволин. - 2003. - С. 34-36.

9. Хендель Н. В. Міжнародно-правове регулювання співробітництва держав у ссрері охорони здоров'я : дис. на здобуття наукового ступеня кандидата юридичних наук / Н. В. Хендель. - 2014. - 256 с.

10. Царик Г. Н. Общественное здоровье и здравоохранение / Г. Н. Царик. - Кемерово, 2012. - 911 с. 


\section{References}

1. Hrytsenko, O.A. Zdorovia liudyny yak obiekt pravovoho rehuliuvannia [Human health as an object of legal regulation]. Retrieved from: http://hnpu.edu.ua/sites/default/files/files/Kaf_zdor_ta_korr_os/Zagalna_teorija_zdorovia_i_ zdorviazberegennja.pdf [in Ukrainian].

2. Huseva, H.V., \& Ubohov, S.H. (2016). Zakonodavchi aspekty zabezpechennia dotrymannia etychnykh norm u sferi okhorony zdorovia [Legislative aspects of ensuring ethical compliance in the healthcare sector]. Intehratyvna Antropolohiia - Integrative Anthropology, 1 (27), 17-21 [in Ukrainian].

3. Etychnyi kodeks farmatsevtychnykh pratsivnykiv Ukrainy [Code of Ethics for Pharmaceutical Workers of Ukraine]. Retrieved from: http://nuph.edu.ua/etichnijj-kodex-farmacevtichnih-prac/ [in Ukrainian].

4. Kovtun, L., Yankova, L., Rasputnyak, S., Silantieva, O., Maltseva, Y., Popova, L., Kalashnikov, M., Fedorchuk, T. (2017). Zahalni pryntsypy orhanizatsii diialnosti komisii z pytan etyky pry likuvalno-profilaktychnykh zakladakh, vyakykh provodiatsia klinichni vyprobuvannia likarskykh zasobiv [General principles for organizing the activities of ethics committees at health care facilities where clinical trials of medicinal products are conducted]. Kyiv [in Ukrainian].

5. Zanfirova, T.A., \& Radysh, Ya.F. Etyko-pravovi zasady rehuliuvannia medychnoi diialnosti v Ukraini (za materialamy literaturnykh dzherel) [Ethical and legal principles of regulation of medical activity in Ukraine (based on materials of literary sources)]. Retrieved from: http://medicallaw.org.ua/uploads/media/02_124_01.pdf [in Ukrainian].

6. Zaporozhan, V.M., \& Ariaev, M.L. (2013). Bioetyka ta biobezpeka. [Bioethics and biosafety]. Kyiv. Zdorovia [in Ukrainian]. 7. Mizhnarodni etychni rekomendatsii shchodo doslidzhen, poviazanykh iz zdoroviam, za uchastiu liudei [International ethical guidelines for human-related research]. Retrieved from: http://www.dec.gov.ua/site/files/clinic/cioms.pdf [in Ukrainian].

8. Ramishvili, A.D., Viter, V.I., \& Nevolin, N.I. (2003). Sovremennyye problemy etiki i prava v zdravookhranenii [Modern problems of ethics and law in health care]. [in Russian].

9. Handel, N.V. (2014). Mizhnarodno-pravove rehuliuvannia spivrobitnytstva derzhav u sferi okhorony zdorovia [International legal regulation of state cooperation in the field of health care]. Candidate's thesis [in Ukrainian].

10. Tsarik, G.N. (2012). Obshchestvennoye zdorovye i zdravookhraneniye [Public health and health care]. Kemerovo [in Russian]

\section{ПРАВОВЫЕ И ЭТИЧЕСКИЕ ОСНОВЫ ОБЩЕСТВЕННОГО ЗДОРОВЬЯ}

\section{Е. А. Терзи ${ }^{1}$, Н. А. Ляхова ${ }^{2}$, Т. В. Плужникова ${ }^{2}$}

${ }^{1}$ Одесский национальный медицинский университет, г. Одесса, Украина

²ВГУЗУ «Украинская медицинская стоматологическая академия», г. Полтава, Украина

Цель: проанализировать правовые и этические основы общественного здоровья.

Материалы и методы. Методы исследования выбраны с учетом поставленной цели исследования. Для установления объективности и обоснованности научных положений, выводов, в ходе проведенного исследования использовали комплекс общенаучных и специальных научных методов, таких, как: фрормально-юридический метод использовали для проведения анализа правовых и этических основ общественного здоровья; с помощью сравнительно-правового метода выяснено подходы национального законодательства и международных стандартов к нравственному компоненту общественного здоровья, в частности этическая составляющая в правовом регулировании деятельности врачей, фрармацевтических специалистов, защите пациентов, проведении медицинских исследований и испытаний; метод прогнозирования и моделирования использовали для разработки практических рекомендаций относительно значения анализа правовых и этических основ общественного здоровья в процессе реформирования системы здравоохранения Украины и имплементации Соглашения об ассоциации между Украиной и Европейским Союзом; метод системного анализа позволил исследовать правовые и этические основы общественного здоровья как компонент системы здравоохранения Украины; историко-правовой метод позволил выявить особенности эволюции правовых и этических основ общественного здоровья.

Результаты. Эффективность правового регулирования общественного здоровья напрямую зависит от соответствия данных норм права принципам морали и этики. Правовым и этическим обязательством врача есть абсолютное уважение к жизни человека, сохранение и восстанавление физического и психического здоровья людей. Этические и правовые нормы в сорере общественного здоровья отражены и в рекомендательных документах, посвященных защите прав пациентов.

Выводы. Положения национального законодательства и международных стандартов в сфере общественного здоровья сочетают правовые и этические основы при регулировании деятельности врачей, фрармацевтических специалистов, защите пациентов, проведении медицинских исследований и клинических испытаний. Эффективность и высокий уровень необходимого обеспечения общественного здоровья неразрывно связаны в реформировании системы здравоохранения Украины в соответствии с международными стандартами, которые сочетают в себе этическую составляющую.

КЛЮЧЕВЫЕ СЛОВА: общественное здоровье; здравоохранение; права пациентов; медицинское право. 
LEGAL AND ETHICAL FRAMEWORKS OF PUBLIC HEALTH

O. O. Terzi', N. O. Liakhova ${ }^{2}$, T. V. Pluzhnikova ${ }^{2}$

${ }^{1}$ Odesa National Medical University, Odesa, Ukraine

${ }^{2}$ Ukrainian Medical Stomatological Academy, Poltava, Ukraine

Purpose: to analyze legal and ethical frameworks of public health.

Materials and Methods. The research methods were chosen taking into account the aim of the study. In order to establish objectivity and validity of scientific provisions, conclusions, during the research, a set of general scientific and special scientific methods was used, in particular such as: formal legal method was used to analyze the legal and ethical frameworks of public health; using the comparative legal method to find out the approaches of national legislation and international standards to the ethical component of public health, in particular the ethical component in the legal regulation of the activities of doctors, pharmaceutical specialists, patient protection, medical research and clinical trials; the method of forecasting and modeling was used to develop practical recommendations on the importance of analyzing the legal and ethical frameworks of public health in the process of reforming Ukraine's health care system and implementing the Association Agreement between Ukraine and the European Union; the method of systematic analysis allowed to study the legal and ethical frameworks of public health as a component of the health care system of Ukraine; the historical and legal method has revealed the peculiarities of the evolution of legal and ethical frameworks of public health.

Results. Efficiency of legal regulation of public health depends on compliance with these law principles of morality and ethics. It is the legal and ethical obligation of the doctor to have absolute respect for human life and to preserve and restore the physical and mental health of people. Ethical and legal norms in the field of public health are also reflected in the guidelines on the protection of patients' rights.

Conclusions. Therefore, the provisions of national law and international standards in the field of public health combine legal and ethical frameworks in regulating the activities of physicians, pharmaceutical professionals, patient protection, medical research and clinical trials. The effectiveness and the highest level of public health care required is inextricably linked to the reform of Ukraine's health care system in accordance with international standards that combine ethics.

KEY WORDS: public health health care; patients' rights; World Health Organization; medical law.

Рукопис надійшов до редакції 28.08.2019 p.

\author{
Відомості про авторів: \\ Терзі Олена Олександрівна - кандидат юридичних наук, доцент Одеського національного медичного універ- \\ ситету; тел.: +38(093) 430-77-77.
}

Ляхова Наталія Олександрівна - викладач кафедри соціальної медицини, організації та економіки охорони здоров'я з біостатистикою ВДНЗУ «Українська медична стоматологічна академія»; тел.: +38(050) 614-76-38.

Плужнікова Тетяна Владиславівна - кандидат медичних наук, старший викладач кафедри соціальної медицини, організації та економіки охорони здоров'я з біостатистикою ВДНЗУ «Українська медична стоматологічна академія»; тел.: +38(095) 206-44-14. 